\title{
Popliteal Lymph Node
}

National Cancer Institute

\section{Source}

National Cancer Institute. Popliteal Lymph Node. NCI Thesaurus. Code C53146.

Lymph node located within the fat layer of the knee joint. 